\title{
Application of WaSiM-ETH model to Northern German lowland catchments: model performance in relation to catchment characteristics and sensitivity to land use change
}

\author{
H. Bormann ${ }^{1}$ and S. Elfert ${ }^{2}$ \\ ${ }^{1}$ Department for Biology and Environmental Sciences, University of Oldenburg, Oldenburg, Germany \\ ${ }^{2}$ Department of Geosciences, University of Bremen, Bremen, Germany
}

Received: 19 January 2010 - Revised: 12 May 2010 - Accepted: 13 May 2010 - Published: 23 August 2010

\begin{abstract}
The hydrological catchment model WaSiMETH (Water Balance Simulation Model) is a spatially distributed, process- and grid-based hydrological catchment model which was primarily developed to simulate the water balance of mountainous catchments. In this study, the ability of WaSiM-ETH was tested to describe the hydrological processes of lowland catchments. In addition, the resulting model performance was related to subcatchment characteristics and the model's sensitivity to possible future land use change. The prediction of the hydrological effects of land use change is a major challenge in contemporary hydrological model applications. The study revealed that WaSiMETH is a suitable tool for the simulation of the hydrological behaviour of lowland catchments. However, for a few subcatchments model validation failed. Analysing the correlation between model performance and physiographic catchment characteristics revealed that WaSiM-ETH performs better in sloped catchments compared to plane ones. Modelling results were also better in heterogeneous catchments with respect to soils and vegetation compared to homogenous ones. However, the hydrological reaction to land use change scenarios was similar in all investigated catchments.
\end{abstract}

\section{Introduction}

The assessment of the impacts of environmental changes is an important task in contemporary hydrological research. In addition to climate, land use is a key factor controlling the hydrological behaviour of catchments (Hörmann et al., 2005). Land use change generally is assumed to cause changes in hydrological dynamics of catchments (Huisman et al., 2009).

\section{Correspondence to: $\mathrm{H}$. Bormann}

(helge.bormann@uni-oldenburg.de)
Different approaches are possible to identify land use change effects. Based on available long-term data, statistics can reveal the contribution of land use change to hydrological change (e.g., Siriwardena et al., 2006). Similarly, paired catchment studies can be carried out to reveal differences in the hydrological behaviour (e.g., Brown et al., 2005). However, these techniques are able to analyse the effects of historical land use change, only. Aiming on future developments, land use change scenarios can be used to draw a picture of future conditions and to assess the effects of the expected changes.

Models, suitable for scenario analyses, must have been validated for current conditions in advance. Therefore, hydrological models mostly are set-up for current land use first, defining the expected future changes, running the model again for land use scenario conditions and, finally, quantifying the differences between the two sets of simulations (e.g., Bhaduri et al., 2000; Niehoff et al., 2002; Ott and Uhlenbrook, 2004; Huisman et al., 2009).

In this study, the physically based and distributed hydrological catchment model WaSiM-ETH (Schulla, 1997) is calibrated and validated for the Northern German lowland Hunte river. It is then applied to IPCC based agricultural land use scenarios (Ewert et al., 2005; Rounsevell et al., 2005). Due to the lack of appropriate regional studies, the large scale IPCC-based scenarios serve as a set of possible future land use developments. Based on this set of simulations we try to relate the performance of the model application to physiographic catchment characteristics. In addition, the sensitivity of WaSiM-ETH to land use scenarios is related to model performance to be able to estimate the applicability of WaSiM-ETH model within land use change scenario studies in lowland environments. 


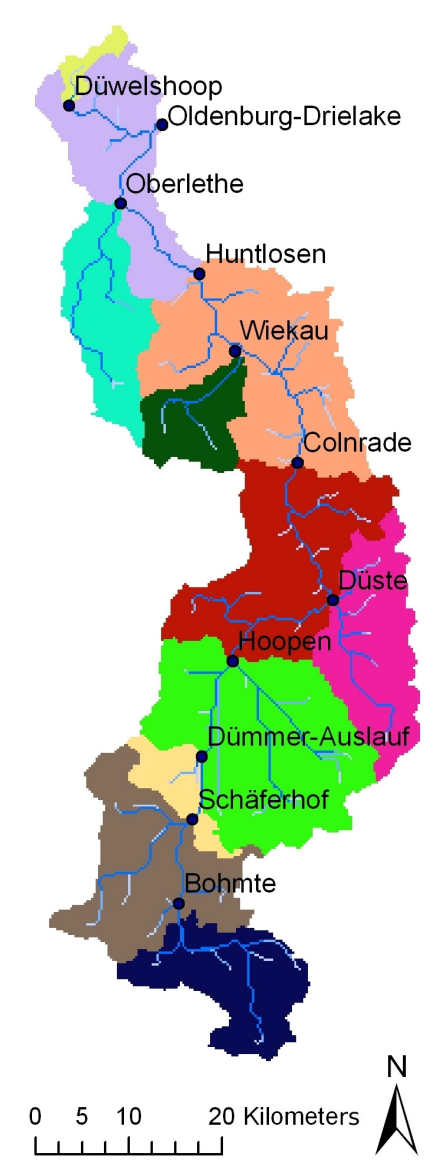

Fig. 1. Catchment of the Hunte river, showing 10 subcatchments with available gauge data used for the model application.

\section{Material and methods}

\subsection{WaSiM-ETH model}

The hydrological catchment model WaSiM-ETH (Water Balance Simulation Model; Schulla, 1997) is a spatially distributed, process- and grid-based hydrological catchment model. Primarily, it was developed for the quantification of climate change effects in mountainous catchments. Despite focusing on the spatial variability of atmospheric boundary conditions WaSiM-ETH represents all relevant hydrological processes. In this study, the physically based version of WaSiM-ETH is used, based on the representation of the soil water flow using the Richards' equation. Evapotranspiration is calculated based on the Penman-Monteith approach, and groundwater flow processes are described using a 2-D Darcy-based groundwater module. An overview on the representation of the hydrological processes in WaSiM-ETH is given by Table 1 .

Different studies are available in which WaSiM-ETH was applied to determine the effect of land use change and land cover on the water balance (Krause et al., 2007; Bormann et al., 2007; Huisman et al., 2009; Elfert and Bormann, 2010) as well as on floods (Verbunt et al., 2005) and storm runoff generation (Niehoff et al., 2002). All these analyses have been performed at different spatial scales, from small headwater catchments of a couple of $\mathrm{km}^{2}$ up to large river catchments of more than $100000 \mathrm{~km}^{2}$, and in different environments (mainly mountainous regions, but also lowlands).

\subsection{The Hunte catchment}

The Northern German Hunte river catchment is selected to test the applicability of the WaSiM-ETH model under lowland conditions. The catchment of the Hunte, contributing downstream to the Weser river, has a size of $2141 \mathrm{~km}^{2}$ at gauge Oldenburg-Drielake (Fig. 1). The climate of the Hunte catchment is humid with a mean air temperature of $9.5^{\circ} \mathrm{C}$ and a mean annual precipitation of about $780 \mathrm{~mm}$. The topography of the southern upstream catchment part is characterised by low mountains (highest elevation of $247 \mathrm{~m}$ a.s.l.) while the central and northern downstream parts are dominated by lowland characteristics (see digital elevation model, Fig. 2). Agricultural land use is intense over the whole catchment. Cropland covers $69 \%$ of the catchment area, followed by forest $(12 \%)$, grassland (9\%), urban areas $(5 \%)$, bogs $(4 \%)$ and open water $(1 \%)$. In the central part of the catchment, significant area of the catchment is covered by organic soils (about $13 \%$ of the total area; $4 \%$ uncultivated raised bogs in the entire catchment).

The data base available for the Hunte catchment comprises spatial data sets of topography (digital elevation model with $50 \mathrm{~m}$ resolution), soils (soil map 1:50000) and land use (CORINE land cover classification; Fig. 2). In addition, time series on daily discharge (11 gauges, see Fig. 1), daily weather data (6 stations) and precipitation data (38 rain gauges) are available for the time period from 1980 to 2005 . Disaggregation of daily weather data to hourly time step is performed according to Bormann et al. (1996).

\subsection{IPCC based land use scenarios}

In order to test the sensitivity of WaSiM-ETH to land use scenarios, agricultural land use scenarios according to Rounsevell et al. (2005) and Ewert et al. (2005) are used for this study. These scenarios are based on the SRES scenarios of the IPCC, taking into account a European and national policy measures to obtain a European specific interpretation of major driving forces (Busch, 2006). They are based on the assumption that increasing $\mathrm{CO}_{2}$-concentration in the atmosphere and changes in climate have minor impacts on agricultural productivity, only. The driving factor of future land use rather is the available technology, including improved machinery, efficiency of pesticides and the growing of new agricultural species. Spatial allocation rules are applied to compute land use patterns (Rounsevell et al., 2005). 
Table 1. Hydrological processes and process descriptions in WaSiM-ETH. For details see Schulla (1997) and www.wasim.ch.

\begin{tabular}{ll}
\hline Process & Process description, reference \\
\hline Potential evapotranspiration (PET) & Penman-Monteith equation; Monteith (1965) \\
Actual evapotranspiration (AET) & AET = $f$ (PET, soil moisture); Jasper et al. (2006) \\
Interception storage (IS) & IS = $f$ (leaf area index) \\
Infiltration & Green and Ampt (1911) approach \\
Unsaturated water flow & Richards' equation \\
Interflow (I) & $I=f$ (saturation, mobile water) \\
Groundwater recharge & Percolation from unsaturated zone to the groundwater table \\
& (dynamic lower boundary condition) \\
Groundwater flow & Darcy equation \\
Lateral exchange between soil/ & LEX $=f$ (Hydraulic gradient, leakage factor) \\
groundwater and rivers (LEX) & \\
\hline
\end{tabular}
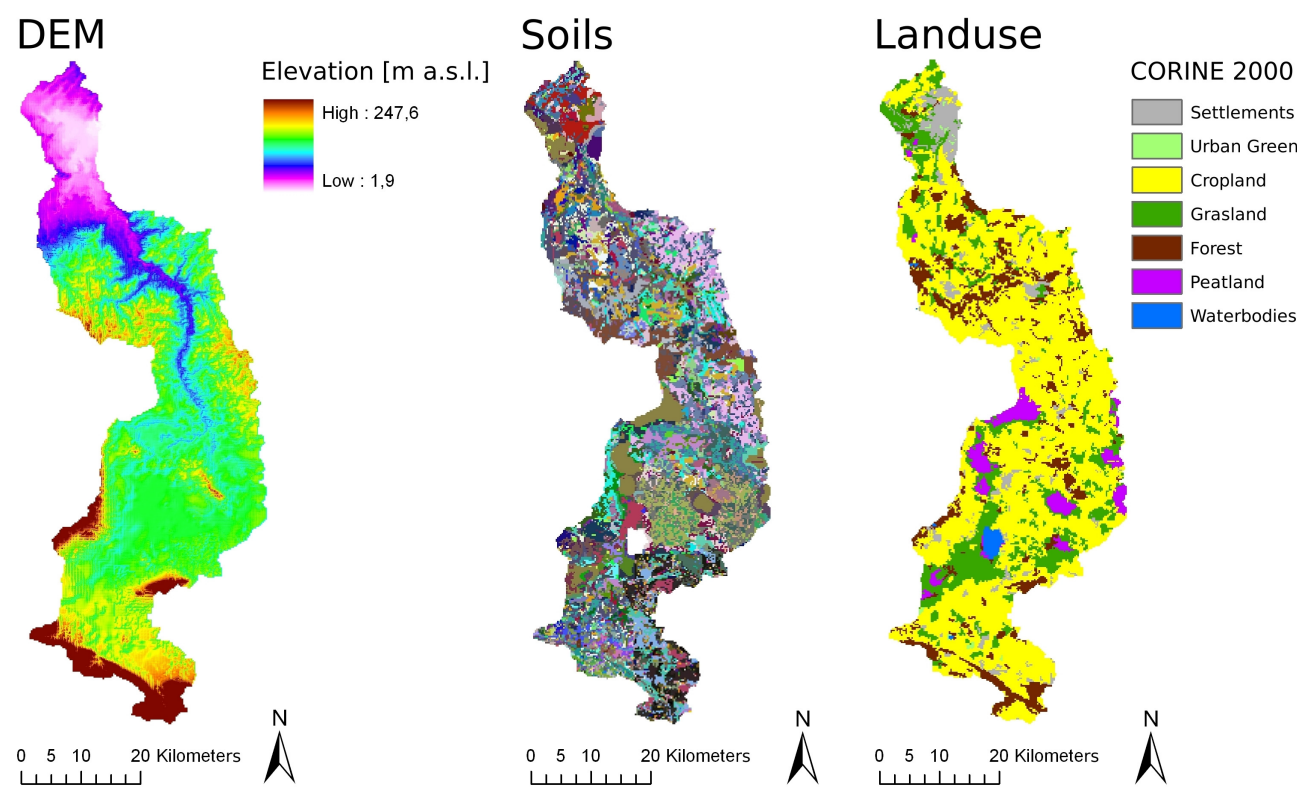

Fig. 2. Physiographic catchment characteristics: topography (digital elevation model, $50 \mathrm{~m}$ resolution), soils (soil map 1:50 000) and current land use (CORINE data set of the year 2000). The soil map does not include a legend due to the large number of different soil types (434 different soil profiles).

All SRES scenarios assume an increase with respect to the relative yield in central Europe. Due to the remarkably increasing productivity, and despite rising demand on food, Rounsevell et al. (2005) projected a decrease in agriculturally used area in central Europe. The projected decrease in agriculturally used area is stronger for the A scenario family compared to the B scenarios (Table 2). To regionalise the national trends projected by Ewert et al. (2005) and Rounsevell et al. (2005) to the scale of the Hunte catchment, the changes projected for two contrasting scenarios A1F1 and B1 are distributed over the current CORINE land use, covering the whole catchment area of the Hunte. For each scenario, three options of change are investigated because the land use
Table 2. Corine land cover of the Hunte catchment for the year 1990 (CLC, 1990) versus average changes in agricultural land use in Germany according to the land use scenarios according to Rounsevell et al. (2005) until 2080.

\begin{tabular}{lccccc}
\hline & CLC 1990 & A1F1 & A2 & B1 & B2 \\
\hline Cropland & $69 \%$ & $-47 \%$ & $-45 \%$ & $-26 \%$ & $-25 \%$ \\
Grassland & $9 \%$ & $-47 \%$ & $-56 \%$ & $-19 \%$ & $-41 \%$ \\
\hline
\end{tabular}


after the change was not defined by Ewert et al. (2005) and Rounsevell et al. (2005): (1) change from agricultural land into forest, (2) change from agricultural land into urban area and (3) change from agricultural land into forest and urban area in equal parts. The choice of the pixel being subject to change in land use is based on the distance to existing urban areas, assuming that in case of a change in favour of urban area the already existing urban area would tend to grow.

\section{Model application}

\subsection{Model set-up}

Model set-up and parameterisation are carried out for a $250 \mathrm{~m}$ grid. Bormann et al. (2009) showed for the regional scale Dill river catchment (Hesse, Germany) that WaSiMETH did not react sensitively to an information loss related to data aggregation up to a comparable grid size. The time step of this model application is set to an hourly resolution. Parameterisation of the physical parameters of WaSiM-ETH is mainly based on WaSiM parameter tables and an a priori soil parameter determination applying the pedotransfer function (PTF) of Rawls and Brakensiek (1985). Based on soil texture and porosity, this PTF estimates the soil hydraulic parameters according to Brooks and Corey (1964).

During the scenario analysis, parameterisation of soils and water management (e.g., tile drainage) remain constant while parameterisation of land cover is changed. Following vegetation parameters are altered for calculation of the scenario effects on the water balance: fraction of vegetation cover per cell, albedo, leaf area index, canopy height, canopy resistance, interception capacity, rooting depth, and hydraulic head for beginning dryness stress.

\subsection{Model calibration and validation}

Manual calibration is carried out on parameters of the conceptual model components (e.g., recession parameters of surface runoff and interflow, scaling parameter for the calculation of interflow, leakage factors). Additionally, groundwater parameters (drainable porosity, hydraulic conductivity), river channel parameters (width, depth) and drainage parameters (depth, horizontal spacing) are calibrated as well, because those parameters cannot be derived directly from the data base available. Groundwater parameters are calibrated by optimising simulated river low flows while drainage parameters of the fast runoff components are adjusted in order to improve the correlation under high flow conditions.

Results of the calibration time period (1986-1995) show that WaSiM-ETH can be well adjusted to the discharge data of most of the catchments. For the majority of the 11 subcatchments, discharge dynamics at the catchment outlet is well simulated for low flow conditions, peak flows as well as for the annual discharge amount (model efficiency
(ME): $\mathrm{ME}>0.8$ at four gauges, $\mathrm{ME}>0.7$ at six gauges). Results of three exemplary years of the calibration period are shown in Fig. 3. While highest agreement between simulations and observations is detected for the upper reaches of the Hunte (e.g., Bohmte, Schäferhof), lake Dümmer smoothes the discharge hydrograph observed at the downstream gauges. This is not reflected in the simulations as lake Dümmer is connected to the Hunte river only in high flow situations which cannot be represented in WaSiM-ETH model. This smoothing is noticeable at all downstream gauges (Hoopen, Colnrade), causing at least a slight overestimation of high flows at downstream river gauges. However, simulation quality in terms of model efficiency (Nash and Sutcliffe, 1970), coefficient of determination and water balance error is hardly affected (Fig. 4). In contrast, the discharge dynamics of a few downstream tributaries is not represented satisfactorily by WaSiM-ETH. For example for the Düste and Düwelshoop catchments, high flows are overestimated while for the Wiekau and Oberlethe catchments high flows are underestimated (Fig. 3). This is also reflected by the quality measures (Fig. 4). Lowest model efficiencies as well as highest water balance errors occur at the downstream tributaries. This holds for calibration and validation period. Quality measures for the validation period (1996-2005) of most catchments are similar to those of the calibration period except for the downstream tributaries of the Hunte, for which the simulation quality significantly declines in the validation period. In addition to the differentiation between upstream and downstream tributaries, the results and quality measures show a clear scale effect (Fig. 4). With increasing catchment size, quality measures keep consistently high although fairly simulated downstream tributaries contribute to the hydrographs. Nevertheless, the quality measures of the downstream gauges keep high values for calibration and validation periods. We can assume that this is based on the compensation of different errors contributing to the integral response at the catchment scale.

\subsection{Relating model performance to catchment characteristics}

The different behaviour of upstream and downstream tributaries to the discharge of the Hunte river raises the question in which way different physiographic catchment properties contribute to this phenomenon. Therefore, a systematic, comparative analysis is performed in order to identify possible correlations between catchment characteristics and quality measures of simulated discharge.

Figure 5 summarises selected results of this analysis. Contrasting the model efficiency and the mean absolute water balance error with catchment characteristics reveals that simulation quality declines with decreasing catchment average slope. From this correlation we infer that fast runoff processes are better represented in WaSiM-ETH compared to slow runoff processes which mostly dominate in permeable 

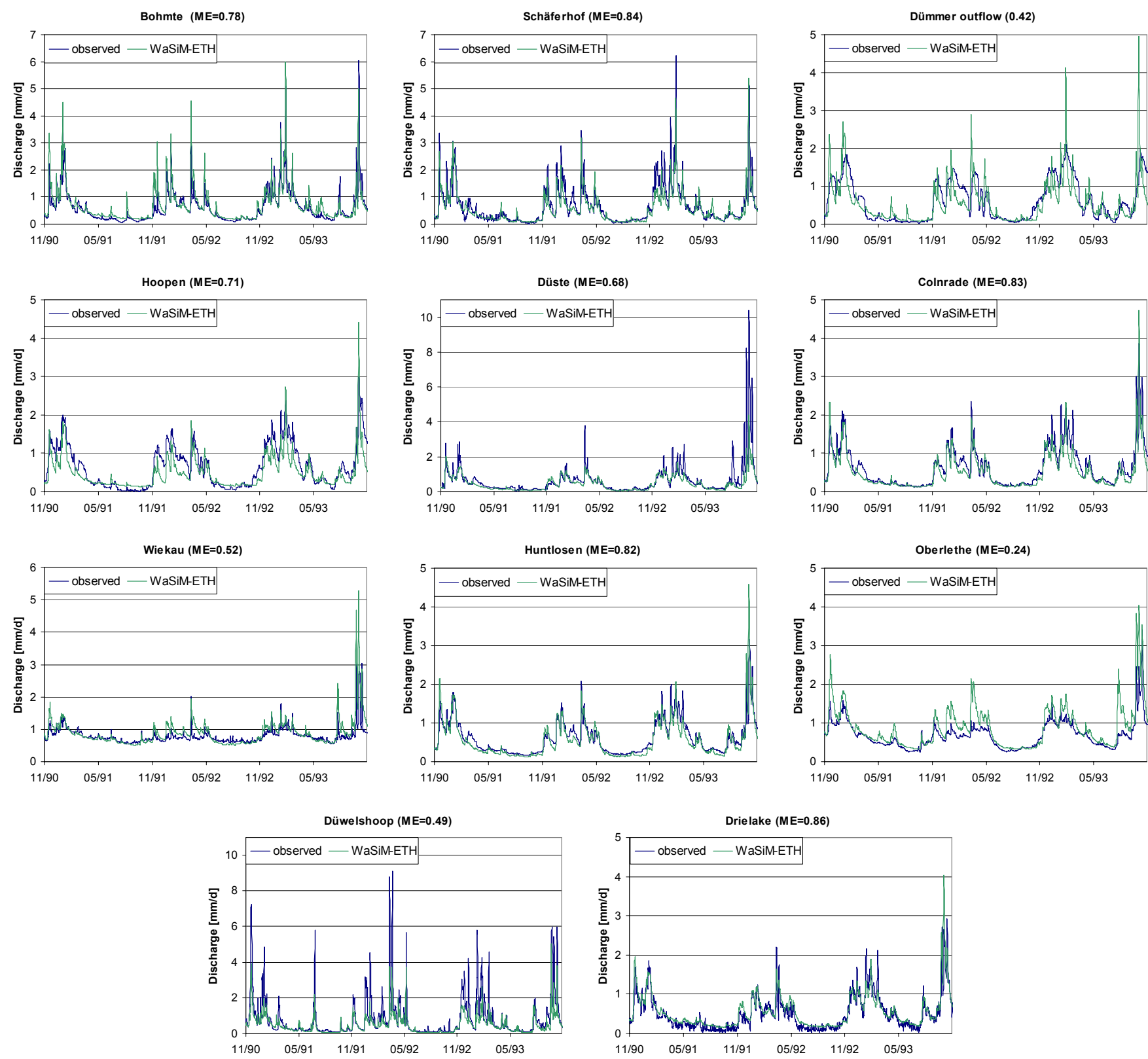

Fig. 3. Observed versus simulated discharges in the calibration period for the Hunte river at Oldenburg-Drielake and the 10 subcatchments (ME = model efficiency for the entire calibration period).

and plane catchments. The analysis furthermore shows that water flows of rural catchments are not as well represented as catchments with a higher percentage in urban area are (Fig. 5). From this correlation we assume that WaSiM-ETH tends to simulate at least a small portion of fast runoff processes based on a parameterisation using the pedotransfer function of Rawls and Brakensiek (1985). Therefore, partly urbanised catchments show better simulation results compared to rural catchments.
Focusing at the forested fraction of the catchments, the results of the correlation analysis reveal that those catchments with particularly small as well as large forested areas show worse quality measures compared to catchments with intermediate forest cover (Fig. 5). This indicates that the plant parameterisation which was taken from WaSiM-ETH parameter tables should be adjusted to the regional conditions. Finally, the results of the correlation analysis show that the simulation quality of those catchments in which a remarkable fraction of the area is dominated by soils retaining 

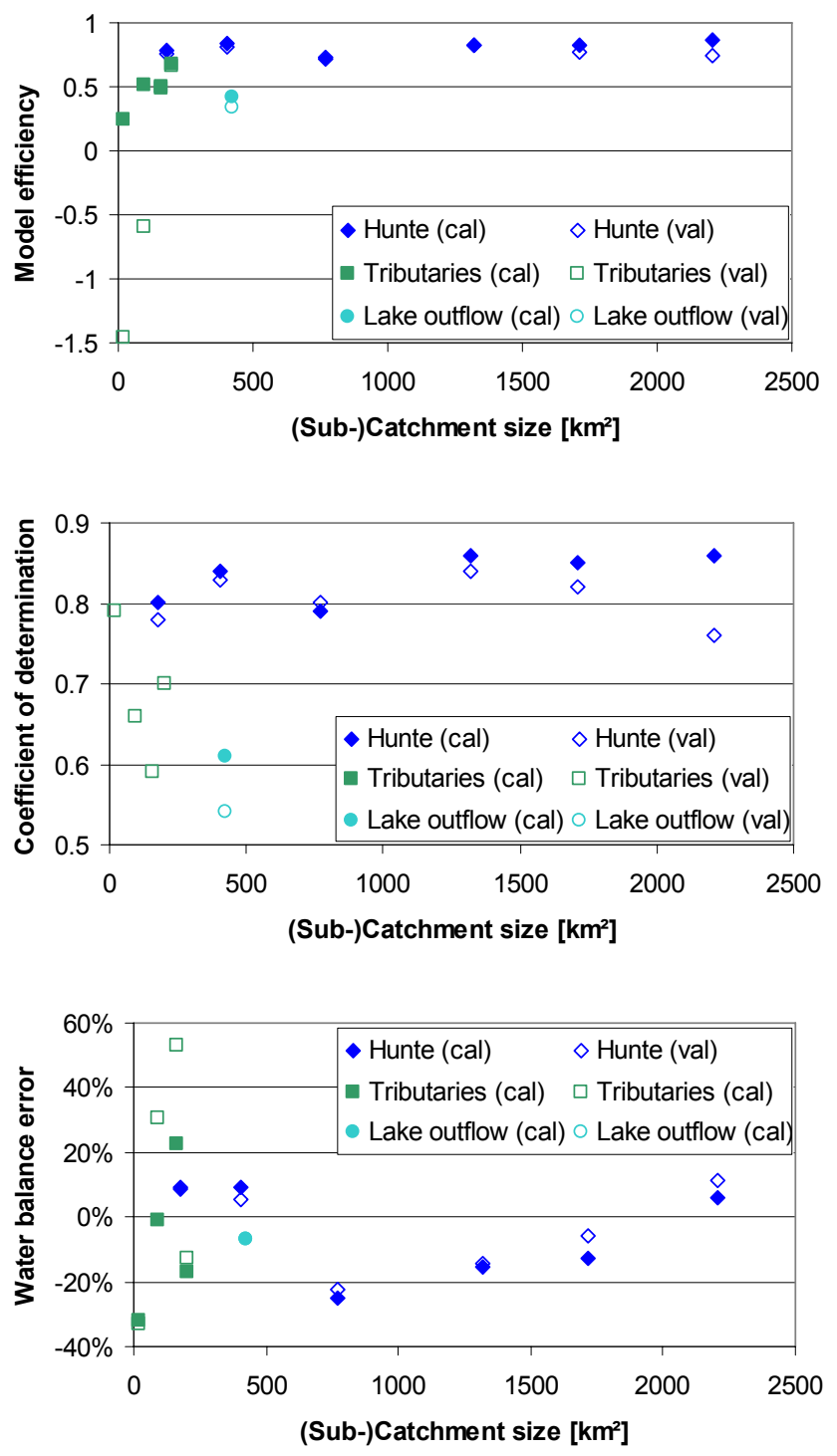

Fig. 4. Scale dependency of different quality measures (model efficiency, coefficient of determination, water balance error) for the calibration (1986-1995) and validation (1996-2005) periods. Subcatchments and their areas: Drielake $\left(2207 \mathrm{~km}^{2}\right)$, Huntlosen $\left(1714 \mathrm{~km}^{2}\right)$, Colnrade $\left(1318 \mathrm{~km}^{2}\right)$, Hoopen $\left(772 \mathrm{~km}^{2}\right)$, Dümmer $\left(426 \mathrm{~km}^{2}\right)$, Schäferhof $\left(403 \mathrm{~km}^{2}\right)$, Düste $\left(200 \mathrm{~km}^{2}\right)$, Bohmte $\left(179 \mathrm{~km}^{2}\right)$, Oberlethe $\left(160 \mathrm{~km}^{2}\right)$, Wiekau $\left(95 \mathrm{~km}^{2}\right)$, and Düwelshoop $\left(22 \mathrm{~km}^{2}\right)$.

infiltrating water (stagnogley area) is remarkable better than those catchments which are dominated by permeable soils (Fig. 5). Similar results were obtained for other soil types, resulting in worse simulation results of catchments with small areal fractions of podzol and organic soils. Comparable to the simulation of urbanised areas, the hydraulic properties of stagnogley soils support the generation of fast flow components resulting in a distinct runoff dynamics.
The correlations identified between physiographic catchment data and model performance measures implicate that parameterisation and process representation are important causes of model errors. This is confirmed by an additional investigation analysing possible effects of a varying density of rain gauges which often is a major source of uncertainty according to Bardossy and Das (2008). However, in contrast to topography, soils and land use, a dependence of simulation quality to the density of available precipitation stations could not be found for the Hunte catchment. Simulation quality is not correlated to the average distance to the next rain gauge within a subcatchment. Therefore, it can be assumed that the physiographic characteristics have major impact on the model validity of WaSiM-ETH in the small lowland tributaries compared to the network of rain gauges.

\subsection{Sensitivity to land use scenarios}

Despite the catchment specific physiographic characteristics and catchment specific quality of simulated discharges, the reaction of WaSiM-ETH as a consequence of land use change scenarios is homogenous over all catchments. Figure 6 shows that the pattern of simulated discharge amounts is almost identical for all subcatchments, indicating a stronger effect of the A1F1 land use change scenario compared to the B1 scenario. For both scenarios the results indicate an increase of discharge for a land use change from agriculture to urban areas, a decrease in simulated discharge for a land use change from agriculture to forested area and rather no change in simulated discharge for a change from agriculture to forested and urban areas in equal parts. Elfert and Bormann (2010) assume that effects of partial land use changes compensate each other. Simulation results based on the Corine land cover data of the years 1990 and 2000 are almost identical due to minor changes in the land use $(<1 \%)$, only.

\section{Discussion}

Correlating the simulation quality to topographic catchment properties reveals that simulation quality is better for hilly catchments compared to flat catchments. From this correlation we infer that those runoff generation processes which are dominant in hilly catchments are better represented in WaSiM-ETH compared to those runoff generation processes dominating in flat areas. This finding is in a good agreement with the fact that WaSiM-ETH was developed for alpine (or at least hilly) catchments where fast runoff processes play a dominant role compared to slow ones. For better representation of lowland hydrological processes, Krause et al. (2007) coupled WaSiM-ETH to a 3-D-groundwater model (MODFLOW) in order to improve the dynamics of the groundwater flow. This is, for example, in accordance with the model structure of Mike-SHE (Refsgaard and Storm, 1995) which was developed for the simulation of lowland areas, in particular. In Mike-SHE, a full groundwater model is integrated. 

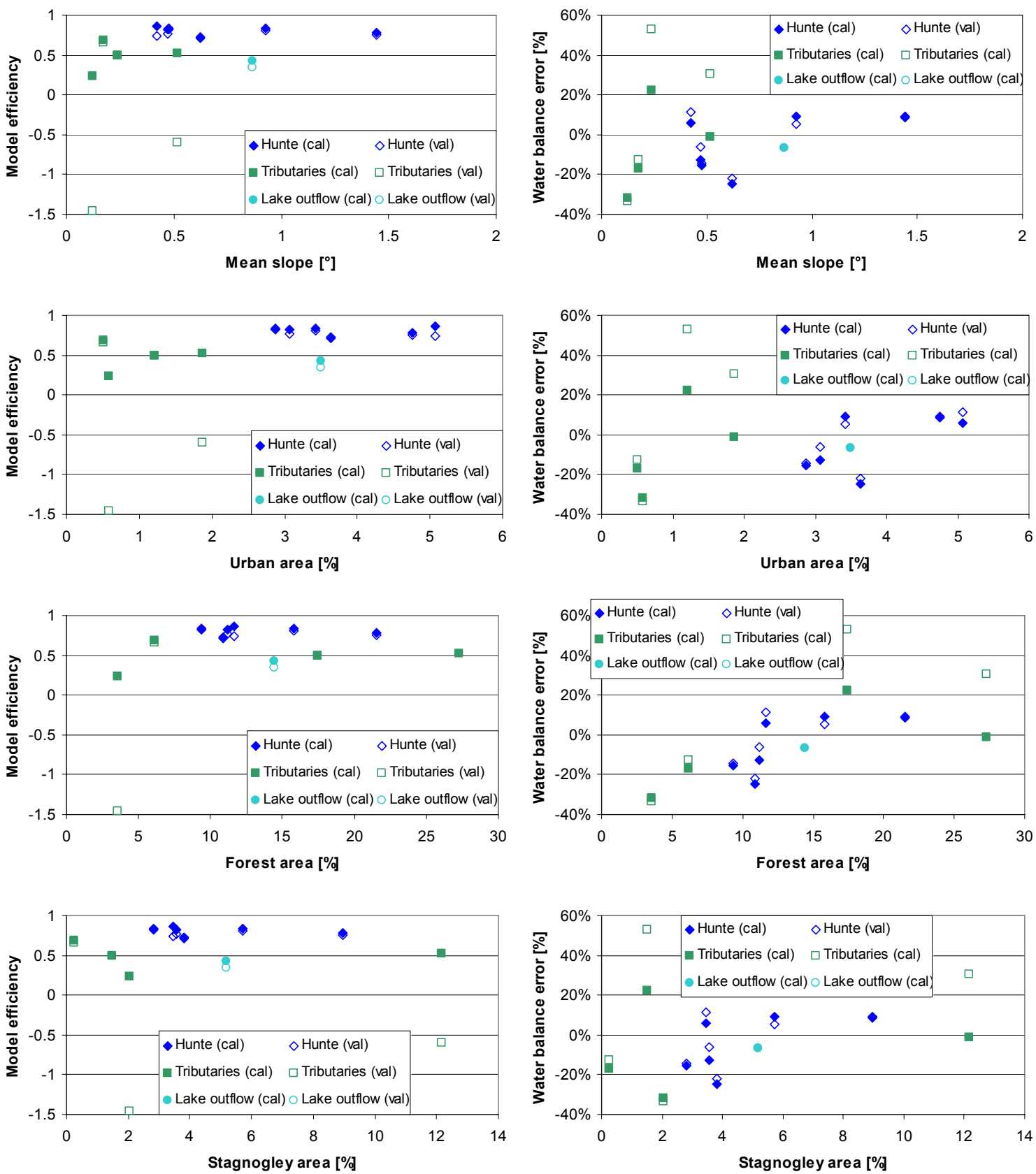

Fig. 5. Correlation of quality measures (model efficiency, mean absolute annual water balance error) to selected physiographic catchment characteristics: mean slope $\left[{ }^{\circ}\right]$, urban area [\%], forest area [\%], stagnogley soils [\%].

Deducing from the correlation results of quality measures to areal fractions of soil types and land uses we assume that WaSiM-ETH behaves better in heterogeneous compared to homogenous catchments. This statement depends on the choice of the parameterisation approach, in our case aiming at minimum calibration on the one hand (parameter determination based on transfer functions) and a region-wide parameterisation of land use and soil classes instead of a sub-catchment specific parameter calibration. Including lo- cal scale knowledge into parameterisation should improve simulation quality significantly for homogenous catchments, as well. Errors in parameterisation are most likely to compensate for heterogeneous catchments compared to homogenous areas. Similarly, sub-catchment specific model calibration should improve the subcatchment specific model performance but would limit the transferability of a model set-up to another catchment. 

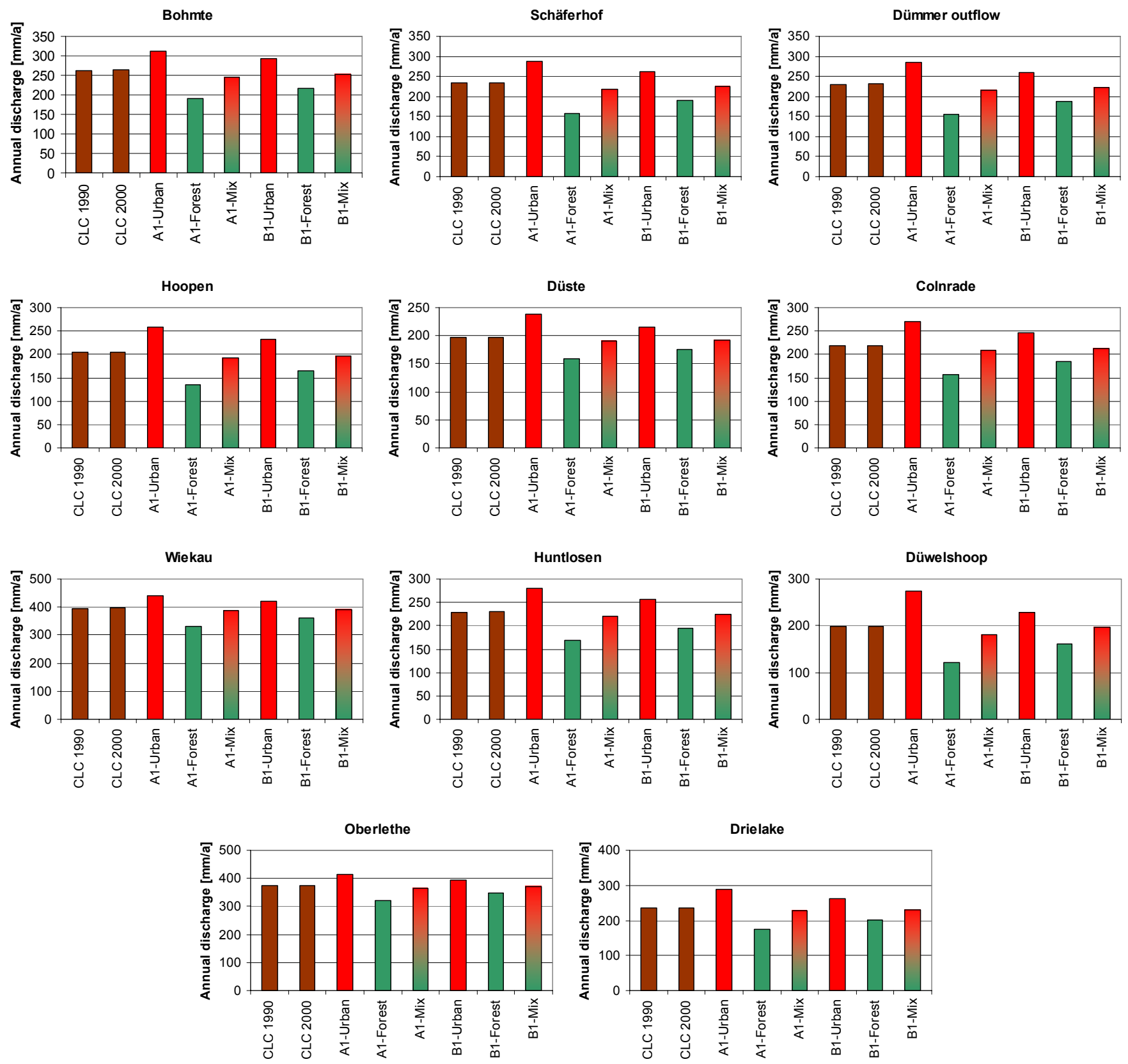

Fig. 6. Catchment specific changes in discharge due to land use change scenarios. CLC $1990=$ CORINE land cover data from year 1990; CLC 2000 = CORINE land cover data from year 2000; A1 = IPCC scenario A1F1; B1 = IPCC scenario B1; urban = change from agriculture to urban area, only; forest = change from agriculture to forest area, only; mix = change from agriculture to forest and urban area in equal parts.

Analysing the effect of land use change on different runoff generation processes (surface runoff, interflow, baseflow), Elfert and Bormann (2010) report that even the catchment specific reaction of those different runoff generation mechanisms is homogenous among the subcatchments of the Hunte river. In general they show that, in agreement with the results showed in Fig. 6, WaSiM-ETH is sensitive to the land use change scenarios composed by Ewert et al. (2005) and
Rounsevell et al. (2005). But they also state that the choice of the final land use (land use after the change: forest versus urban area) is more important compared to the choice of the land use change scenario (A1F1 versus B1), reducing the value of the land use change scenario because WaSiM-ETH is more sensitive to the assumptions to be made compared to the information provided by the land use change scenario. However, the simulated hydrological change due to land use 
change scenarios is significant, confirming the findings of other land use scenario studies which considered sealed areas as part of their land use scenario studies (e.g., Ott and Uhlenbrook, 2004; Bhaduri et al., 2000). Other studies assuming moderate changes in vegetation cover (e.g., cropland, grassland, forest), only, resulted in considerably smaller hydrological effects of land use change (e.g., Huisman et al., 2009). This highlights that a careful definition of scenarios is essential.

\section{Conclusions}

This study revealed that WaSiM-ETH is suitable to be successfully applied to lowland catchments in terms of model efficiency, although the model seems to show limitations in the representation of slow, groundwater based hydrological processes. However, the performance of WaSiM-ETH was acceptable in most of the investigated lowland subcatchments.

Main reasons for the differing simulation quality can be assumed to be related to the specific catchment characteristics which were not captured by the catchment wide model parameterisation and minimum calibration strategy. The correlation analysis showed a decreasing quality of model simulations with decreasing catchment slope and for increasingly homogenous subcatchments. Subcatchment specific parameter calibration should improve the model performance but would limit the transferability of the model set-up, including the parameterisation approach.

Simulation quality obviously showed a scale effect. With increasing catchment size the quality measures improved. The effect of only fairly simulated water flows of downstream tributaries was small. It therefore can be assumed that errors are averaging out with increasing catchment size and with increasing heterogeneity of a catchment.

Finally, the application of WaSiM-ETH to IPCC-based land use scenarios revealed a plausible hydrological reaction to land use change. A validation of such large sensitivity is difficult due to the fact that fast and intensive land use changes occur rarely and are not often hydrologically monitored. Therefore, further action should focus on carrying out model intercomparison studies with respect to model sensitivity to land use change such as done by Huisman et al. (2009). The sensitivity of individual models to land use change is more reliable if different models show similar sensitivities to the same land use change scenario.

Acknowledgements. The authors thank the EU-Interreg IVb programme for the funding of the "Climate Proof Areas" project and several organisations for providing physiographic catchment data: the Bundesanstalt für Gewässerkunde (BfG, Koblenz), the Landesamt für Bergbau, Energie und Geologie (LBEG, Hannover), and the Niedersächsischer Landesbetrieb für Wasserwirtschaft, Küstenund Naturschutz (NLWKN, Brake/Oldenburg).
Edited by: A. Wahren, F. Tavares Wahren, and K.-H. Feger Reviewed by: A. Münch and another anonymous referee

\section{References}

Bárdossy, A. and Das, T.: Influence of rainfall observation network on model calibration and application, Hydrol. Earth Syst. Sci., 12, 77-89, doi:10.5194/hess-12-77-2008, 2008.

Bhaduri, B., Harbor, J., Engel, B., and Grove, M.: Assessing watershed-scale, long-term hydrologic impacts of land-use change using a GIS-NPS model, Environ. Manage., 266, 64358, 2000.

Bormann, H., Breuer, L., Croke, B., Gräff, T., and Huisman, J. A.: Assessing the impact of land use change on hydrology by ensemble modelling (LUCHEM) IV: Model sensitivity on data aggregation and spatial (re-) distribution, Adv. Water Resour., 32, 171-192, 2009.

Bormann, H., Breuer, L., Gräff, T., and Huisman, J. A.: Analysing the effects of soil properties changes associated with land use changes on the simulated water balance: A comparison of three hydrological catchment models for scenario analysis, Ecol. Model., 209, 29-40, 2007.

Bormann, H., Diekkrüger, B., and Richter, O.: Effects of data availability on estimation of evapotranspiration, Phys. Chem. Earth., 21(3), 171-175, 1996.

Brooks, R. H. and Corey, A. T.: Hydraulic properties of porous media. Colorado State University, Fort Collins, Colorado, 27 pp., 1964.

Brown, A. E., Zhang, L., McMahon, T. A., Western, A. W., and Vertessy, R. A.: A review of paired catchment studies for determining changes in water yield resulting from alterations in vegetation, J. Hydrol., 310, 28-61, 2005.

Busch, G.: Future European agricultural landscapes - What can we learn from existing quantitative land use scenarios?, Agr. Ecosyst. Environ., 114, 121-140, 2006.

Elfert, S. and Bormann, H.: Simulated impact of past and possible future land use changes on the hydrological response of the northern German lowland "Hunte" catchment, J. Hydrol., 383, 245-255, 2010.

Ewert, F., Rounsevell, M. D. A., Reginster, I., Metzger, M., and Leemans, R.: Future scenarios of European agricultural land use. I. Estimating changes in crop productivity, Agr. Ecosyst. Environ., 107, 101-116, 2005.

Green, W. H. and Ampt, G. A.: Studies of soil physics. Part 1. The flow of air and water through soils, J. Agr. Sci., 4, 1-24, 1911.

Hörmann, G., Horn, A., and Fohrer, N.: The evaluation of land-use options in mesoscale catchments - Prospects and limitations of eco-hydrological models, Ecol. Model., 187, 3-14, 2005.

Huisman, J. A., Breuer, L., Bormann, H., Bronstert, A., Croke, B. F. W., Frede, H.-G., Gräff, T., Hubrechts, L., Jakeman, A. J., Kite, G., Leavesley, G., Lanini, J., Lettenmaier, D. P., Lindström, G., Seibert, J., Sivapalan, M. G., Viney, N. R., and Willems, P.: Assessing the impact of land use change on hydrology by ensemble modelling (LUCHEM) III: scenario analysis, Adv. Water Resour., 32, 159-170, 2009.

Jasper, K., Calanca, P., and Fuhrer, J.: Changes in summertime soil water patterns in complex terrain due to climatic change, J. Hydrol., 327, 550-563, 2006. 
Krause, S., Jacobs, J., and Bronstert, A.: Modelling the impacts of land-use and drainage density on the water balance of a lowlandfloodplain landscape in northeast Germany, Ecol. Model., 200, 475-492, 2007.

Monteith, J. L.: Evaporation and environment, in: The state and movement of water in living organism, edited by: Fogy, G. T., Cambridge University Press, 205-234, 1965.

Nash, J. E. and Sutcliffe, J. V.: River flow forecasting through conceptual models, part I - a discussion of principles, J. Hydrol., 10, 272-290, 1970.

Niehoff, D., Fritsch, U., and Bronstert, A.: Land-use impacts on storm-runoff generation: scenarios of land-use change and simulation of hydrological response in a meso-scale catchment in SW-Germany, J. Hydrol., 267, 80-93, 2002.

Ott, B. and Uhlenbrook, S.: Quantifying the impact of land-use changes at the event and seasonal time scale using a processoriented catchment model, Hydrol. Earth Syst. Sci., 8, 62-78, doi:10.5194/hess-8-62-2004, 2004.

Rawls, W. J. and Brakensiek, D. L.: Prediction of soil water properties for hydrological modelling, in: Proceedings of the symposium watershed management in the eighties, edited by: Jones, E. and Ward, T. J., Denver, 293-299, 1985.
Refsgaard, J. C. and Storm, B.: MIKE SHE, in: Computer models of watershed hydrology. Highlands Ranch, edited by: Singh, V. P., Water Resources Publications, 809-46, 1995.

Rounsevell, M. D. A., Ewert, F., Reginster, I., Leemans, R., and Carter, T.R.: Future scenarios of European agricultural land use. II. Projecting changes in cropland and grassland, Agr. Ecosyst. Environ., 107, 117-135, 2005.

Schulla, J.: Hydrologische Modellierung von Flußgebieten zur Abschätzung der Folgen von Klimaänderungen Züricher Geographische Schriften, Verlag Geographisches Institut ETH Zürich, 69, 161 pp., 1997 (in German).

Siriwardena, L., Finlayson, B. L., and McMahon, T. A.: The impact of land use change on catchment hydrology in large catchments: The Comet River, Central Queensland, Australia, J. Hydrol., 326, 199-214, 2006.

Verbunt, M., Groot Zwaaftink, M., and Gurtz, J.: The hydrologic impact of land cover changes and hydropower stations in the Alpine Rhine basin, Ecol. Model., 187, 71-84, 2005. 